\title{
A LONG-TERM LAND COVER AND LAND USE MAPPING METHODOLOGY FOR THE ANDEAN AMAZON
}

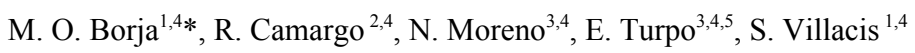 \\ ${ }^{1}$ Fundación EcoCiencia, San Ignacio E12-143 and Humboldt, Quito, Ecuador 170517 - maolgaborja@gmail.com, \\ sylviavillacis@ecociencia.org \\ ${ }^{2}$ Fundación Amigos de la Naturaleza/FAN, Km. 7 1/2 Doble Vía La Guardia, Bolivia - rcamargo@fan-bo.org \\ ${ }^{3}$ Instituto del Bien Común/IBC, Av. Salaverry 818, Lima11-Perú - (deforestacion.ibc2, deforestacion.ibc4)@gmail.com \\ ${ }^{4}$ Member - Red Amazónica de Información Socioambiental Georreferenciada/RAISG \\ ${ }^{5}$ Universidad Nacional Agraria La Molina, PDRH, Av. La Molina s/n La Molina, Lima-Perú
}

KEY WORDS: Andes, Remote sensing, Land use, Amazon, Monitoring, Bolivia, Ecuador, Peru

\begin{abstract}
:
The data developed by the MapBiomas Amazon initiative (http://amazonia.mapbiomas.org/) led by the Amazon Geo-referenced Socio-environmental Information Network's (RAISG) is of unprecedented spatial and temporal resolution for the Andes region. It's comprised by a series of annual maps for the years 2000 to 2017 that allow to monitor the extent of transformation in this region using a single regional methodological approach. Several variables were included to solve Andes-specific methodological challenges and they represent adaptations of RAISG's Amazonian methodology to the Andean region. Among such, is the use of the novel NDFIb index (Turpo, 2018), an adaptation of the NDFI index that aims at mapping Andean Wetlands. Glaciers identification was aided by the fractional abundance of snow (Turpo, 2018), as well as small water bodies identification with McFeeters (1996) NDWI water index. This experience unfolds promising accessibility to novel land cover and land use regional reconstructions and comparisons possible only by the use of large-scale cloud-computing data processing tools, open source technology, spatially and temporally comprehensive remote sensing data, along with RAISG's standardized protocols and frameworks.
\end{abstract}

\section{INTRODUCTION}

The Amazon is the world's largest continuous forest, yet it is under threat as it faces large forest cover conversion due to deforestation related to agricultural expansion and infrastructure development. Given its extent and remoteness, remote sensing data is nowadays the primary source of information to monitor land cover change in this region.

The Amazon Geo-referenced Socio-environmental Information Network (RAISG) is a consortium of civil society organizations from the Amazonian countries oriented towards the socio-environmental sustainability of the Amazon. Focused on achieving an integral vision of the region, RAISG generates and disseminates knowledge, statistical data and geospatial socio-environmental information of the Amazon elaborated with common protocols and frameworks for all the countries of the region. RAISG has prepared various remote sensing-derived deforestation maps of the Amazon (RAISG, 2012; RAISG, 2015) for the periods 2000-2005, 2005-2010, 2010-2015; which can be downloaded from RAISG's website (https://www.amazoniasocioambiental.org/es/).

Recent technological advancements of cloud-based satellite imagery processing tools enabled the network to generate a 1st Collection of 2000-2017 land cover and land use annual maps for the entire Amazon region aimed at understanding the processes that are transforming its landscape. Known as the MapBiomas Amazon initiative, it is led by RAISG and based on the methodology built for the biomes of Brazil by the MapBiomas initiative (https://mapbiomas.org/).

For the MapBiomas Amazon Collection 1 of land cover and land use annual maps, RAISG's mapping limit was extended with respect prior mapping efforts to include the watershed divides along the Andes, totalling an extension of 8,449,321 $\mathrm{km} 2$, covering the Amazon River basin territories of Bolivia, Brazil, Colombia, Ecuador, Guyana, French Guiana, Peru, Suriname and Venezuela, including part of the Orinoco river basin and its delta, the Cuyuní, Esequibo, Suriname and other coastal rivers of the three Guianas (Figure 1).

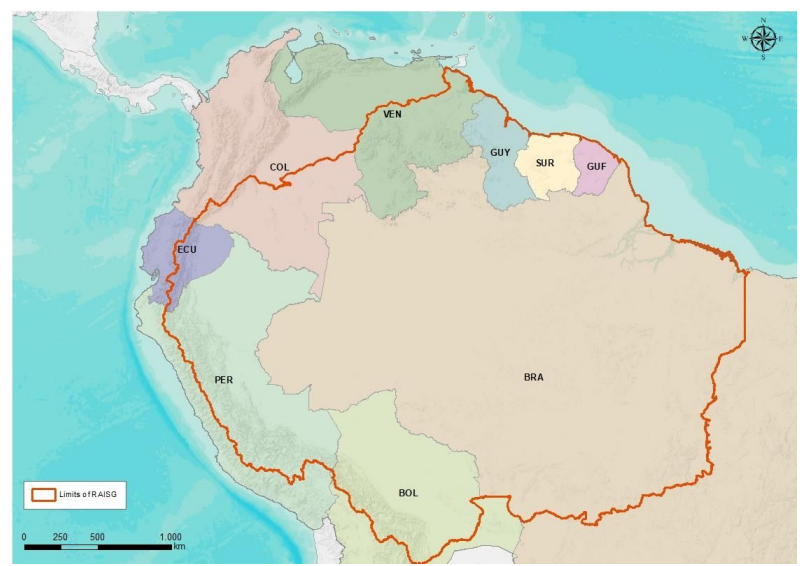

Figure 1. Territory of the Pan-Amazonian region defined by the watershed divide limit, and the countries that comprise it: BOL

(Bolivia), BRA (Brazil), COL (Colombia), ECU (Ecuador),

(GUF) French Guiana, GUY ( Guyana), PER (Peru), SUR

(Suriname), VEN (Venezuela).

RAISG has defined six biomes or regions with differentiated biogeographical, phenological and orographic characteristics within the Pan-amazon: Amazon, Cerrado, Chaco-Chiquitano, Pantanal, Bolivian Tucumano and Andes. Each possess a series of distinct methodological challenges. The latter of which corresponds to the study area and focus of this document. Due 
to the extent of its transformation and its relevance to the local and regional water cycle, the temporal monitoring of Andean ecosystems is of uttermost importance.

\section{MAIN BODY}

\section{$2.1 \quad$ Study area}

Covering an area of $261,978 \mathrm{~km} 2$ or barely $3.1 \%$ of the total RAISG geographical scope (Table 1), the Andes portion of the Amazon Basin corresponds to the Atlantic slope of the Andes. This region is characterized by the presence of a mountain range cordillera with the same name that encompasses an area between $0^{\circ} 49^{\prime}$ North and $20^{\circ} 21^{\prime}$ South and acts as a natural barrier between the coastal and amazonian regions of the continent. Ecologically, its ecosystems range between montane to subnival and nival bioclimatic floors (MAE, 2013). Its relief is mountainous, with valleys of glacial and/or tectonic origin, and its landscape is composed of volcanoes, craters, lava deposits and steep hills between which plains and extensive inter-Andean valleys are located. Glaciers cover several mountain tops, from which thaw forms lagoon systems, wetlands and thin water bodies that make up the headwaters of the Amazon Basin.

\begin{tabular}{|l|c|c|}
\hline \multicolumn{1}{|c|}{ Country } & Surface $(\mathrm{Km} 2)$ & $\%$ \\
\hline Bolivia (BOL) & 52,244 & 7 \\
\hline Ecuador (ECU) & 30,189 & 23 \\
\hline Peru (PER) & 179,545 & 23 \\
\hline Total & 261,978 & \\
\hline
\end{tabular}

Table 1 . Andes region per country as total surface and as a percentage of country's mapped area within RAISG's limit.

The upper (westmost) limit of the Amazon hydrographic region (i.e. the summit of the Andes mountain range) was defined based on the official cartographic information of watershed divides provided: for Bolivia by the Ecorregion limit (Ibisch 2003) and Puna Norteña class; for Ecuador, by the SENAGUA (2014) and CONALI (2016); and for Peru, by ANA (2014). The lower limit was defined following biogeographic criteria (Figure 2).

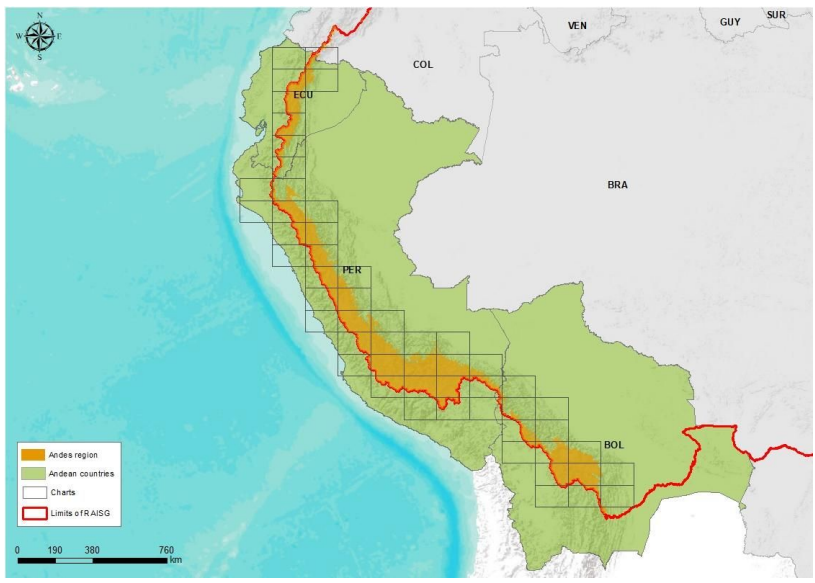

Figure 2. Andes biome defined within BOL (Bolivia), ECU

(Ecuador) and PER ( Peru), for the MapBiomas Amazon

Collection 1 of land cover and land use annual maps.

The dominant vegetation physiognomy of the Andes are natural grasslands and shrub formations. In Bolivia, this grass-dominated cover with scattered bushes is called Puna, and it generally grows above 4000 meters of altitude. The soils are generally dry, although there are flooded peatlands (bofedales). Andean forest formations occur to a lesser extent. Dry inter-Andean forests are characterized by low, deciduous and thorny canopies, 3 to $5 \mathrm{~m}$ high, with trees and emerging columnar cacti of up to $10 \mathrm{~m}$ in height, while others are semi-deciduous forests, with a tree canopy of 10 to $15 \mathrm{~m}$ high, and emerging trees that may reach up to $20 \mathrm{~m}$. Polylepis forests (kewiñales), are scattered at over $2500 \mathrm{~m}$ of altitude

The Ecuadorian Andes range between 2300-5800 meters of altitude. Montane forests occur in areas of ecological transition to amazonian forests at lower altitudes. Canopy height reduces with increasing altitude, transitioning to shrub-dominated vegetation, natural grasslands and forest relics adapted to high altitude conditions. These natural non forest formations are commonly known as páramos, and some of them might be permanently or seasonally flooded peatlands. The vegetation might even become nil at exposed rock outcrops, sand, scars of eruptive events and glaciers. Much of this region has been transformed to anthropogenic uses, including agriculture, pastures, human settlements and infrastructure.

For mapping purposes, the Peruvian Andes were further subdivided in 3 sub-regions: Andes, Andean dry forest, and Andean transitional forest. The Peruvian Andes have altitudes that range between 2000 and 6000 meters of altitude. The area is characterized by steep terrains and various altitudinal floors that generate different microclimates and therefore very different ground cover types. The peruviuan Andean dry forest is characterized by scatteredly distributed low canopy arboreal communities and rocky outcrops between 500 and 2400 meters of altitude. They occur at the base of deep inter-Andean valleys of the Marañón, Huancabamba, Pampas, Pachachaca and Apurímac rivers. The peruvian Andean transitional forest limits with the uppermost Amazon biome limit and receives a strong humidity influence from this biome.

\section{$2.2 \quad$ Data}

The mapping data used was obtained from the Landsat Data Archive (LDA) provided by NASA and the United States Geological Survey (USGS), and accessed through the Google Earth Engine (EE) platform (Gorelick et al 2016). The Surface Reflectance images belong to the data catalog with Tier 1 correction level, which were subjected to radiometric calibration, orthorectification based on ground control points, and digital elevation models to ensure pixel co-registration and atmospheric correction. The Landsat images of 30 meter spatial resolution cover all the years between 2000 and 2017 and were obtained by the Landsat Thematic Mapper (TM), Enhanced Thematic Mapper Plus (ETM+) and Operational Land Imager and Thermal Infrared Sensor (OLI-TIRS), on board of the Landsat 5, Landsat 7, and Landsat 8 satellites. A combination of Landsat 5 and Landsat 7 data was also used.

\section{$2.3 \quad$ Data processing}

The MapBiomas processing chain is based entirely on Google's cloud computing technology. Satellite images were processed and classified using Google EE Code Editor using the following sequence (Figure 3): 1) annual reflectance data mosaics were generated; 2) variables were derived from the reflectance data; 3) spectral collection was conducted to identify the set of variables that best discriminates between classes; 4) 
classification was performed using decision trees; 5) where needed, classes that were mapped as cross-cutting subjects were integrated into the map; 6) spatial and temporal filters were applied to remove noise and fill data gaps; 7) land use change and cover maps were published along with statistics.

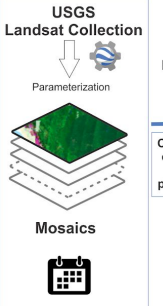

Asset 1

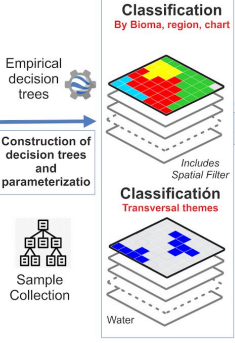

Asset 2
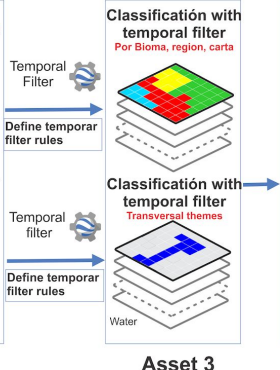

Asset 3
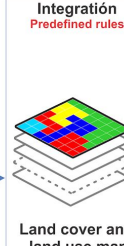

land use map
2000-2017

Asset 4
Figure 3. MapBiomas Amazon processing chain.

The MapBiomas methodology divides the study area into a grid of regular charts. The charts are defined based on the grid of The International Map of the World, at a 1:250,000 scale. Each rectangular chart covers an area of $1^{\circ} 30$ 'longitude by $1^{\circ}$ latitude and may require a combination of total and partial Landsat images. A total of 55 charts cover the Andes biome (Figure 2). Each chart was processed and classified individually. Charts shared by more than one sub-region were divided and processed separately, facilitating a decision tree parameterization adjusted to the land cover specificities of each portion.

2.3.1 Annual mosaics: Annual mosaics of Landsat image pixels were generated for each chart or section of a chart. Clouds and shadows were masked to ensure only cloud-free pixels would be selected from the available images. An optimal period for mosaic composition was defined, based on seasonality and climatic characteristics of the region, looking for the time of the year with the greatest spectral contrast between forested and non-forested classes.

For each mosaic, a set of parameters were defined by the interpreter: 1) year, 2) initial and end date, 3) sensor, and 4) maximum cloud cover. A median reflectance value was calculated for each pixel using the above mentioned criteria, generating a unique annual value that is subject to classification. Each interpreter aimed to achieve the least possible presence of clouds and interferences while searching for the greatest coverage of data within the defined period.

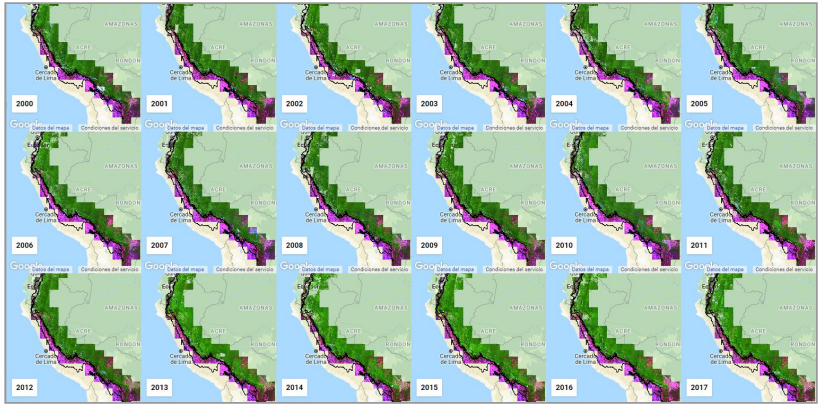

Figure 4. Annual series of mosaics processed for the Andes biome for years 2000 to 2017 .
A total of 990 mosaics were processed for the entire Andes region (Table 2, Figure 4).

\begin{tabular}{|l|c|c|}
\hline & Charts & Total mosaics \\
\hline Bolivia & 16 & 288 \\
\hline Ecuador & 8 & 144 \\
\hline Peru & 31 & 558 \\
\hline Total & 55 & 990 \\
\hline
\end{tabular}

Table 2. Total mosaics processed per country and for the entire Andes region for the 2000-2017 time series.

2.3.2 Variables: 28 variables were derived from the reflectance data, including: 1) spectral fractions from spectral mixture analysis -SMA- (subpixel fractional abundance of photosynthetic vegetation -GV-, non-photosynthetic vegetation -NPV-, soil, cloud, shade, shade normalized photosynthetic vegetation -GVs- and snow); 2) indexes (Normalized Difference Fraction Index -NDFI-, Normalized Difference Vegetation Index -NDVI-, Modified Normalized Difference Water Index (Gao) -NDWI-, Soil-adjusted Vegetation index -SAVI-, Modified Enhanced Vegetation Index -EVI2-, Forest canopy index -FCI-, Savanna ecosystem fraction index -SEFI-, Wetland Ecosystem Fraction Index -WEFI-, Non-photosynthetic vegetation and soil addition, Difference Index between green vegetation, non-photosynthetic vegetation and soil, Wet Vegetation Index -WVI-, Range (amplitude) between minimum and maximum NDFI value, Modified Standardized Difference Water Index (mcfeeters) -NDWI_mcfeeters-, NDFI adaptation for the Andes -NDFIb-; 3) elevation data and masks (Elevation, Slope, Hillshade mask, Water mask, Cloud mask, Shade mask, Modified shade mask). The Landsat reflectance bands only served as input data for the calculation of the variables but not as direct classification variables.

2.3.3 Spectral collection. A subset of the most suitable variables for class discrimination was supported by a spectral collection process executed directly in the EE Code Editor (Figure 5) and a class separability analysis. A total of 18 variables were selected for classification (Table 3).
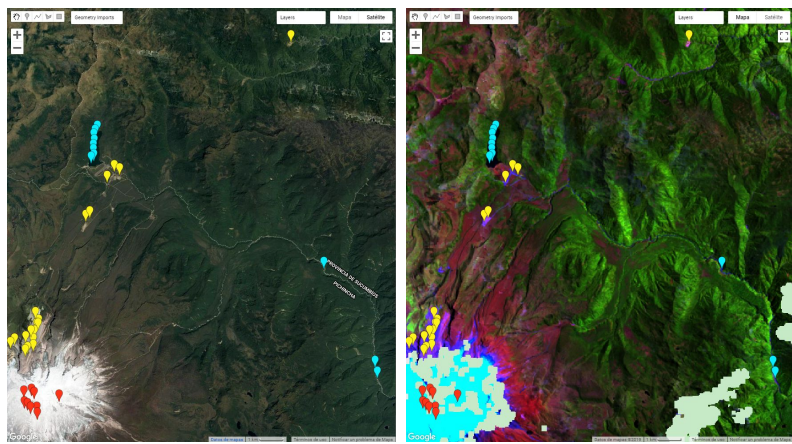

Figure 5. Spectral collection in a region in the Ecuadorian Andes using Google's EE: glacier (red), water (cyan) and non vegetated areas (yellow) points over a) reference high resolution image and b) a 5-4-3 bands Landsat 7 composite for year 2001.

\begin{tabular}{|l|c|c|c|c|}
\hline Variable & BOL & ECU & PER & Formula \\
\hline GV & & & X & \\
\hline NPV & & X & & \\
\hline Soil & X & & X & \\
\hline Cloud & X & X & X & \\
\hline Snow & X & X & X & \\
\hline
\end{tabular}




\begin{tabular}{|c|c|c|c|c|}
\hline GVs & X & X & $\mathrm{X}$ & $\begin{array}{l}\quad G V /(G V+N P V+\text { Soil }+ \\
\quad \text { Cloud })\end{array}$ \\
\hline Shade & $X$ & X & & $\begin{array}{l}\begin{array}{l}100-(G V+N P V+\text { Soil }+ \\
\text { Cloud })\end{array} \\
\text { where: } \\
\text { GV: fractional abundance of } \\
\text { photosynthetic vegetation, } \\
\text { NPV: fractional abundance of } \\
\text { non-photosynthetic vegetation, } \\
\text { Soil: fractional abundance of } \\
\text { soil, Cloud: fractional } \\
\text { abundance of cloud }\end{array}$ \\
\hline NDFI & & & X & $\begin{array}{l}(G V s-(N P V+\text { Soil })) /(G V s+ \\
\quad(N P V+\text { Soil })) \\
\text { where: } \\
\text { GVs: shade normalized } \\
\text { fractional abundance of } \\
\text { photosynthetic vegetation, } \\
\text { NPV: fractional abundance of } \\
\text { non-photosynthetic vegetation, } \\
\text { Soil: fractional abundance of } \\
\text { soil }\end{array}$ \\
\hline EVI2 & & X & X & $\begin{array}{l}(2.5 *(N I R-R E D) /(N I R+2.4 \\
\quad * \text { RED }+1) \\
\text { where: } \\
\text { NIR: Near infrared reflectance } \\
\text { band, RED: Red reflectance } \\
\text { band }\end{array}$ \\
\hline FCI & & & X & $\begin{array}{l}\text { (GV - Shade }) /(G V+\text { Shade) } \\
\text { where: } \\
\text { GV: fractional abundance of } \\
\text { photosynthetic vegetation, } \\
\text { Shade: see shade (equation 2) }\end{array}$ \\
\hline SEFI & $\mathrm{X}$ & X & & $\begin{array}{l}\quad \begin{array}{l}(G V+N P V s-\text { Soil }) /(G V+ \\
\\
\quad N P V s+\text { Soil })\end{array} \\
\text { where: } \\
\text { GV: fractional abundance of } \\
\text { photosynthetic vegetation, } \\
\text { NPVs: shade normalized } \\
\text { fractional abundance of } \\
\text { non-photosynthetic vegetation, } \\
\text { Soil: fractional abundance of } \\
\text { soil }\end{array}$ \\
\hline WVI & & $X$ & & $\begin{array}{l}\quad N D V I+N D W I=((N I R- \\
R E D) /(N I R+R E D))+((N I R- \\
\quad S W I R) /(N I R+S W I R)) \\
\\
\text { where: } \\
\text { NIR: Near infrared reflectance } \\
\text { band, RED: Red reflectance } \\
\text { band, SWIR: Shortwave }\end{array}$ \\
\hline
\end{tabular}

\begin{tabular}{|c|c|c|c|c|c|}
\hline & & & & Infrared reflectance band & \\
\hline $\begin{array}{l}\text { NDWI } \\
\text { mcfeeters }\end{array}$ & $\mathrm{X}$ & & $\mathrm{X}$ & $\begin{array}{l}\text { (GREEN - NIR)/(GREEN + } \\
\qquad N I R) \\
\text { where: } \\
\text { NIR: Near infrared reflectance } \\
\text { band, GREEN: Green } \\
\text { reflectance band }\end{array}$ & \\
\hline NDFIb & $\mathrm{X}$ & & $\mathrm{X}$ & $\begin{array}{l}\text { GVs- (NPV+Soil + Snow)/ } \\
\text { GVs + (NPV + Soil + Snow) } \\
\text { where: } \\
\text { GVs: shade normalized } \\
\text { fractional abundance of } \\
\text { photosynthetic vegetation, } \\
\text { NPV: fractional abundance of } \\
\text { non-photosynthetic vegetation, } \\
\text { Soil: fractional abundance of } \\
\text { soil, Snow: fractional } \\
\text { abundance of snow. }\end{array}$ & \\
\hline Elevation & $\mathrm{X}$ & $X$ & $\mathrm{X}$ & $\begin{array}{l}\text { Elevation from Digital } \\
\text { Elevation Model (Jarvis et., al, } \\
\text { 2008) }\end{array}$ & \\
\hline Slope & $\mathrm{X}$ & $\mathrm{X}$ & $\mathrm{X}$ & $\begin{array}{l}\text { Slope derived from the Digital } \\
\text { Elevation Model (fuente) }\end{array}$ & \\
\hline $\begin{array}{l}\text { Water } \\
\text { mask }\end{array}$ & & $X$ & & $\begin{array}{l}\quad(G V \leq 10) \text { and (Shade } \geq 75) \\
\quad \text { and (Soil } \leq 5) \\
\text { where: } \\
\text { GV: fractional abundance of } \\
\text { photosynthetic vegetation, Soil: } \\
\text { fractional abundance of soil, } \\
\text { Shade: see shade (equation 2) }\end{array}$ & \\
\hline $\begin{array}{l}\text { Shade } \\
\text { mask }\end{array}$ & $\mathrm{X}$ & & X & & \\
\hline
\end{tabular}

Table 3. Spectral collection results: set of variables most useful for class discrimination per country.

2.3.4 Classification. The classification method adopted by MapBiomas contemplates the use of empirical decision trees (Figures 6-8) for pixel-to-pixel classification, where class discrimination is based on the value of the variable in relation to the threshold established by the interpreter (a process called parameterization). The classes that we were able to discriminate within the Andes biome using MapBiomas legend are detailed in Table 4.

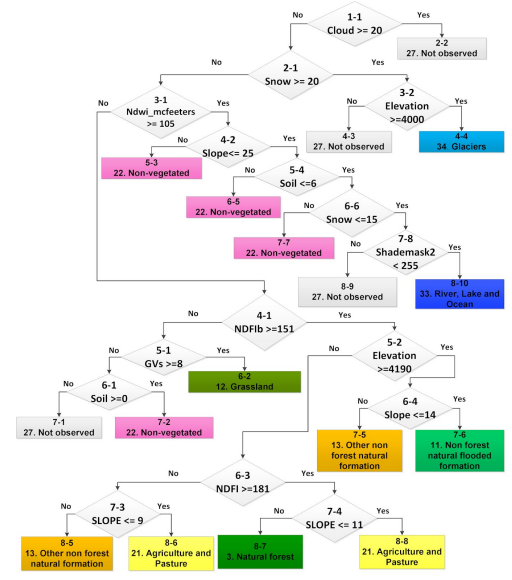

Figure 6: Decision tree used to map the Bolivian and Peruvian Andes. 


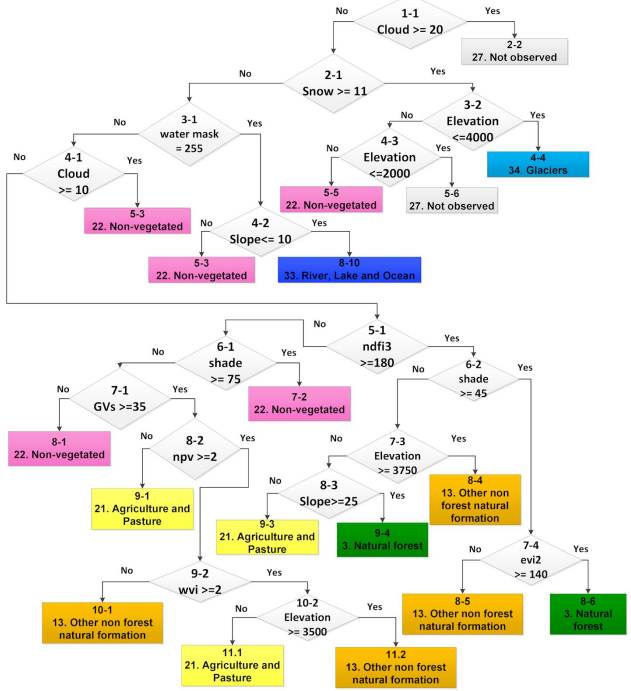

Figure 7: Decision tree used to map the Ecuadorian Andes.

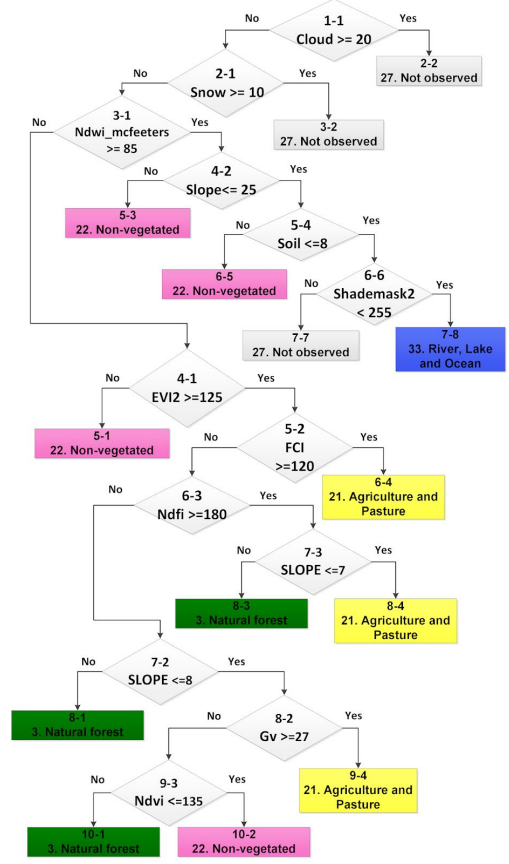

Figure 8: Decision tree used to map the Peruvian Andean dry forest region.

\begin{tabular}{|l|c|c|c|}
\hline Class & BOL & ECU & PER \\
\hline Natural forest & $\mathrm{X}$ & $\mathrm{X}$ & $\mathrm{X}$ \\
\hline Non forest natural flooded formation & & & $\mathrm{X}$ \\
\hline Grassland & & & $\mathrm{X}$ \\
\hline Other non forest natural formation & $\mathrm{X}$ & $\mathrm{X}$ & $\mathrm{X}$ \\
\hline Agriculture and Pasture & $\mathrm{X}$ & $\mathrm{X}$ & $\mathrm{X}$ \\
\hline Non vegetated area & $\mathrm{X}$ & $\mathrm{X}$ & $\mathrm{X}$ \\
\hline River, Lake and Ocean & $\mathrm{X}$ & $\mathrm{X}$ & $\mathrm{X}$ \\
\hline Glacier & $\mathrm{X}$ & $\mathrm{X}$ & $\mathrm{X}$ \\
\hline
\end{tabular}

Table 4. Classes mapped within the Andes biome per country.
2.3.5 Cross-cutting subjects. The 'River, Lake and Ocean' class was independently mapped in the peruvian Andes to improve water body classification results. The results were later integrated with the rest of the classification maps.

2.3.6 Spatial and temporal filters. The spatial filter aims to foster the spatial consistency of the data. Isolated or border pixels may adopt the most abundant surrounding class value based on proximity rules. The filter size ( 3 or 5 pixels) varied depending on the mapped classes. Temporal filters are intended to reduce temporal inconsistencies (i.e. changes in coverage that are not possible or not allowed) based on predefined rules. It also helps to reduce errors due to cloud, haze, and data gaps. Where data gaps remained, the last available information for that specific pixel was applied to the unclassified years.

2.3.7 Maps and statistics. Annual (2000-2017) land cover and land use maps for the Amazonian Andes region are published in http://amazonia.mapbiomas.org/ along with statistics for each year (Figure 9).

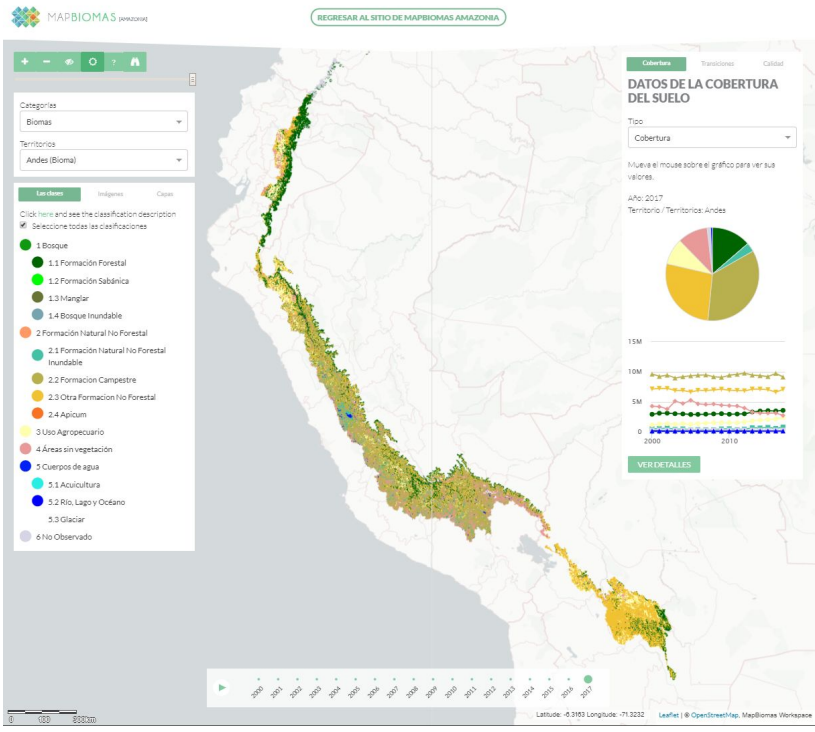

Figure 9: MapBiomas Amazon platform

\section{CONCLUSIONS}

The data developed by the MapBiomas Amazon initiative is of unprecedented spatial and temporal resolution for the Andes region. No other initiative before has generated a series of annual maps that allow to monitor the extent of transformation in this region using a single methodological approach that allows for regional comparisons.

MapBiomas Amazon's Collection 1 of land cover and land use 2000-2017 annual maps are possible only by the use of Google EE platform large-scale processing capabilities, open source technology, spatially and temporally comprehensive remote sensing data form the Landsat missions, along with RAISG's standardized protocols and frameworks. This experience unfolds promising accessibility to novel regional reconstructions and comparisons of the region's past dynamics needed to project present and future actions.

Even though RAISG has an extensive mapping experience in the Amazon Basin, the Andes region represented and extension to its mapping limit and due to its land cover particularities, it 
was not challenge free. This region presents extensive data coverage limitations mainly due to persistent cloud presence. Spectral ambiguity between areas of agricultural use and non-forest natural formations (natural grasslands) represented one of the main classification challenges. Where known agricultural use altitude limits existed, the use of elevation data supported class discrimination.

Spectral mixture analysis (SMA) has proven useful at overcoming conventional image processing limitations in lower-altitude evergreen Amazon rainforest (Souza et al., 2005) and it had been widely used by prior RAISG's forest loss mapping efforts (RAISG, 2012; RAISG, 2015). However, the Andes posed region-specific methodological challenges that required the network to adapt its methodology to the Andes region.

Andean Bofedales discrimination was possible with the use of the novel index NDFIb (Turpo, 2018), an adaptation of the NDFI index that aims at mapping Andean Wetlands. Glaciers identification was aided by the fractional abundance of snow (Turpo, 2018), as well as small water bodies identification with McFeeters' (1996) NDWI water index.

Andean ecosystems are extremely fragile due to the extent of anthropogenic transformation related to human settlements, overgrazing of natural areas, mining concessions, among other pressures, along with global disturbing forces such as climate change, as it's now noticeable seen (visually and quantitatively), for example, by glacier retreat, ecosystem degradation, soil erosion, etc. The Andean region plays a critical role regionally and locally, it's key for ecosystem services provision, such as regional water cycle maintenance, upon which many Andean cities depend for water, food and energy security.

Many local and regional studies can greatly benefit from this data. In the near future, we aim to expand our mapping and monitoring efforts to a more comprehensive time series considering all Landsat data available between 1985 and 2018, using machine learning classification algorithms and independently estimating the precision of our data.

\section{ACKNOWLEDGEMENTS}

The Amazon Geo-referenced Socio-environmental Information Network (RAISG) would like to acknowledge the support of international cooperation whose funding enabled the network to reach this objective. This work was possible by the participation of a network of specialists from each country involved in the mapping within their own political boundaries, and strengthened by the exchange of ideas to develop a joint methodology tailored to the specific needs and variations along the region. The authors would like to thank everyone involved in such process. Also, we would like to thank the constructive revisions of Carmen Josse.
CONALI - Comité Nacional de Límites Internos, 2016. Organización Territorial del Estado.

Gorelick, N., Hancher, M., Dixon, M., Ilyushchenko, S., Thau, D., Moore, R., 2016. Google Earth Engine: Planetary-scale geospatial analysis for everyone. Remote Sens. Environ. 202, $18-27$.

Ibisch P. L., \& Merida, G., 2003. Biodiversidad: La riqueza de Bolivia: Estado de conocimiento y conservación. Ministerios de Desarrollo Sostenible. Editorial FAN, Santa Cruz de la Sierra, Bolivia.

Jarvis, A., H.I. Reuter, A. Nelson, E. Guevara, 2008. Hole-filled SRTM for the globe Version 4, disponible de la base de datos de CGIAR-CSI SRTM 90m http://srtm.csi.cgiar.org/ (30 November 2019)

McFeeters, S. K., 1996. The use of the Normalized Difference Water Index (NDWI) in the delineation of open water features. International Journal of Remote Sensing, v. 17, n. 7, p. $1425-1432$.

MAE - Ministerio del Ambiente del Ecuador, 2013. Metodología para la Representación Cartográfica de los Ecosistemas del Ecuador Continental. Subsecretaría de Patrimonio Natural. Quito.

Turpo E. Y., 2018. Modelagem de mudanças espaço-temporais de ambientes glaciais dos Andes do Sul - Peru. Dissertação (Mestrado em Modelagem em Ciência da Terra e do Ambiente) - Universidade Estadual de Feira de Santana, Feira de Santana, Brazil. 202 f.

RAISG - Red Amazónica de Información Socioambiental Georeferenciada, 2012. Amazonía bajo presión. 68 págs.

RAISG - Red Amazónica de Información Socioambiental Georeferenciada, 2015. Deforestación en la Amazonía (1970-2013). 48 págs.

SENAGUA - Secretaría Nacional del Agua, 2014. Unidades hidrográficas del Ecuador, level 5, 50000 scale.

Souza, C., Roberts, D. A., Cochrane, M. A., 2005. Combining spectral and spatial information to map canopy damage from selective logging and forest fires. Remote Sensing of Environment, v. 98, n. 2-3, p. 329-343.

\section{REFERENCES}

ANA - Autoridad Nacional del Agua. Mapa de Unidades Hidrográficas, 2014 https://sinia.minam.gob.pe/repositorio-de-mapas?page=11 $(22$ March 2019) 